\title{
Mechanical Behavior and Microstructure Evolution of Al-5\% Cu/TiC Metal Matrix Composite
}

\author{
L. Ponraj Sankar ${ }^{1, *}$, R. Kamalakannan ${ }^{2}$, G. Aruna ${ }^{1}$, M.R. Meera ${ }^{3}$, V. Vijayan ${ }^{4}$ and S. Sivananthan ${ }^{5}$ \\ ${ }^{1}$ Department of Civil Engineering, CMR Institute of Technology, Hyderabad, India \\ ${ }^{2}$ Department of Mechanical Engineering, M.Kumarasamy College of Engineering, Karur, India \\ ${ }^{3}$ Department of Physics, Sree Ayyappa College for Women, Chunkankadai. Nagercoil, Tamil Nadu 629003, India \\ ${ }^{4}$ Department of Mechanical Engineering. K.Ramakrishnan College of Technology, Samayapuram, Trichy 621112, India \\ ${ }^{5}$ Department of Mechanical Engineering, K.Ramakrishnan College of Engineering, Trichy, India
}

Corresponding Author Email: ponrajresearch@gmail.com

\begin{abstract}
This paper aims to analyze the mechanical characteristics of Al-5\% Cu/TiC metal matrix composite, like Surface Roughness, Tensile strength, wear rate of the cutting tool. Copper particles added with aluminum alloy, which can improve the machinability and also reduce wear rate. Typically the titanium materials prefer for its excellent strength during the load-carrying process. Here the TiC particles added with aluminum alloy to increase the composite hardness range. The casting samples are machined by the uncoated carbide cutting tool in CNC. The input turning parameters are speed, depth of cut, feed rate, and cutting force. The surface roughness measurement was done after the machining operation. The build-up edge and microstructure behavior of the tool and workpiece were analyzed using Scanning Electron Microscope. The result shows the more Built-up edge formed at low cutting speed and less build-up edge formed at low cutting speed. The higher cutting force indicates the lower cutting speed of 50m/min. The Build-up edges investigated at lower cutting speed and higher cutting speed. While adding $\mathrm{TiC}$ in $\mathrm{Al}-5 \% \mathrm{Cu}$, the elongation of MMC reduced, so it can able to increase the strength of the MMC specimen. Based on these results can able to predict the good mechanical and surface properties of metal matrix composite for the specific application.
\end{abstract}

Keywords: metal matrix composite, build-up edge, machinability, hardness, SEM analysis Received: October-10-2020, Accepted: November-15-2020, https://doi.org/10.14447/jnmes.v23i4.a05

\section{INTRODUCTION}

In recent years metal matrix composite plays a vital role in the making of engine components and other mechanical applications. The metal matrix composite has preferred for its higher strength and good modulus of rigidity. This paper focused on the selection of materials for preparing the metal matrix composite, preparation ratio, and investigate the mechanical and surface properties of MMC. The types of chips formation can fix the quality of the product during the machining process [1-3]. Here this paper discussed the methodology for preparing the MMC, build-up edge formation, and analyzing the mechanical properties. Metal matrix composite is generally classified as in-situ metal matrix composite and ex-situ metal matrix composite. The in-situ metal matrix composite has good wettability and also has powerful bonding with another metal matrix [4, 5]. Ceramic reinforcement of metal matrix composite has got the poor machinability, so while adding the $\mathrm{SiC}$ can slightly improve the machinability. [7, 8]. The standard conventional cutting tool has provided good accuracy at no longer time due to the wear characteristics. So preferred the carbide tool in one of the solutions to wear problems [9]. The study was analyzed the build-up edge, cutting speed, and depth of cut in Al-SiC metal matrix composite, which affects the surface quality. This paper provides the information about excellent surface finish achieved by the maximum cutting speed, minimum depth of cut, and also has the less build-up edge occurred [10, 11]. The number of turning operations on $\mathrm{Al}-25 \% \mathrm{SiC}$ and $\mathrm{CBN}$, silicon nitride inserts carried out by the high-speed lathe using carbide cutting tool. Here cubic boron nitride produces a better result than silicon nitride [14]. The Duplex alloy steel work pieces on the Computer Numerical Controlled (CNC) lathe were machined with cemented carbide tools. The Speed and Depth of cut parameters have a significant effect on MRR. The feed parameter has a big impact on surface roughness $[15,16]$. The machining test was investigated with uncoated carbide cutting inserts on turning Al-4 \% Cu-7.5\% SiC. They employed macro-examination and micro-examination [17]. Based on the literature study, the majority of literature prepares the aluminum alloy with Silicon and Tungsten. This study helps to analyze the various percentage of $\mathrm{TiC}$ and $\mathrm{Cu}$ mixed with aluminum, which is used to improve the strength and toughness of the MMC.

\section{EXPERIMENTAL METHODOLOGY}

\subsection{Preparing the metal matrix composite}

Metal matrix composite prepared using $\mathrm{Al}-5 \% \mathrm{Cu}$ added with $6 \%, 8 \%, 10 \%$ of (TiC) by the in-situ method. The material compositions of MMC are shown in Table 1. Typically Ti has solid materials, so the $99.98 \%$ pure Ti melted in a furnace at $1980^{\circ} \mathrm{C}$ up to 40 miniutes for complete melting. Then the charcoal (grain size $<60 \mu \mathrm{m}$ ) was added with pure titanium and formed the (TiC) Titanium Carbide. Pure aluminum and 5\% Copper added with molten metal in the stir casting. After that, the melting metal poured into the $50 \mathrm{~mm}$ diameter and $300 \mathrm{~mm}$ length mould cavity. The chemical 
bonding of $\mathrm{Al}-5 \% \mathrm{Cu} / \mathrm{TiC}$ is shown in SEM analysis Figure 1 Normally the $5 \% \mathrm{Cu}$ consist with $0.27 \% \mathrm{Mg}, 0.22 \% \mathrm{Fe}$, $0.10 \% \mathrm{Cr}, 0.09 \% \mathrm{Ni}, 0.16 \% \mathrm{Si}$ and $0.14 \% \mathrm{Ti}$.
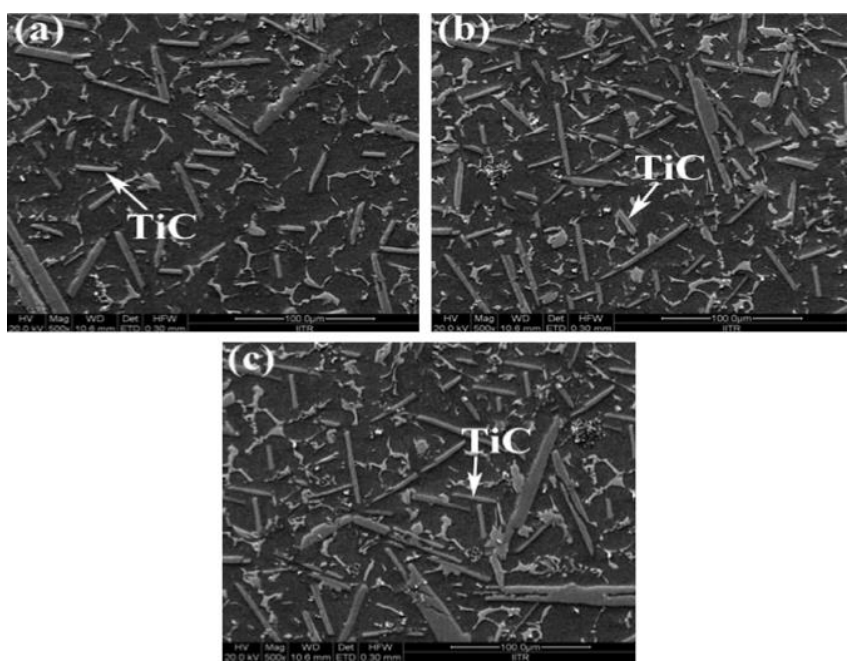

Figure 1. The SEM Analysis (a) Al-5\%Cu/6\% TiC (b) Al$5 \% \mathrm{Cu} / 8 \% \mathrm{TiC}$ (c) $\mathrm{Al}-5 \% \mathrm{Cu} / 10 \% \mathrm{TiC}$

Table 1. Sample Preparation

\begin{tabular}{cccc}
\hline Sample No & Aluminum (\%) & Cu (\%) & TiC (\%) \\
\hline 1 & 88 & 5 & 6 \\
2 & 86 & 5 & 8 \\
3 & 84 & 5 & 10 \\
\hline
\end{tabular}

\subsection{Tensile test and Hardness test}

The tensile workpiece machined $25 \mathrm{~mm}$ gauge length and $5 \mathrm{~mm}$ diameter range at the cylindrical shape, which followed the ASTM E8M-96 standard. The test was carried out at room temperature to maintain a good accuracy result, the hardness value of the three different specimens measured by the Rockwell hardness tester. The Universal Testing Machine measured the tensile strength of MMC. In a hardness test, the five measurements are taken from each sample, and the mean value of the five measurements used for further process, the experimental analysis of hardness, and tensile strength is shown in Table 2.

Table 2. Mechanical Properties of MMC

\begin{tabular}{ccccc}
\hline Composition & $\begin{array}{c}\text { Ultimate } \\
\text { Tensile } \\
\text { Strength } \\
\text { (Mpa) }\end{array}$ & $\begin{array}{c}\text { Elastic } \\
\text { Modulus } \\
\text { (Gpa) }\end{array}$ & $\begin{array}{c}\text { Rockwell } \\
\text { Hardness } \\
\text { (HRL) }\end{array}$ & $\begin{array}{c}\text { Elongation } \\
(\%)\end{array}$ \\
\hline $\begin{array}{c}\mathrm{Al}-5 \% \mathrm{Cu} / 6 \% \\
\mathrm{TiC}\end{array}$ & 143 & 85.98 & 65.26 & 3.12 \\
$\begin{array}{c}\mathrm{Al}-5 \% \mathrm{Cu} / 8 \% \\
\mathrm{TiC} \\
\mathrm{Al}-\end{array}$ & 164 & 93.45 & 72.67 & 2.24 \\
$\begin{array}{c}5 \% \mathrm{Cu} / 10 \% \\
\mathrm{TiC}\end{array}$ & 180 & 98.85 & 76.54 & 1.54 \\
\hline
\end{tabular}

\subsection{Machinability test}

The cutting force analysis of $\mathrm{Al}-5 \% \mathrm{Cu} / \mathrm{TiC}$ composite specimen $(300 \mathrm{~mm}$ length and $50 \mathrm{~mm}$ diameter) in
Conventional lathe by lathe tool dynamometer. The tool dynamometer is attached to the lathe for measuring the cutting force. The uncoated carbide material act as the cutting tool during the turning process in Figure 2. The experimental test were carried out by different speed rate $(50 \mathrm{~m} / \mathrm{min}, 90 \mathrm{~m} / \mathrm{min}$, $130 \mathrm{~m} / \mathrm{min})$, feed rate at $(0.15 \mathrm{~mm} / \mathrm{rev}, 0.25 \mathrm{~mm} / \mathrm{rev}$, $0.35 \mathrm{~mm} / \mathrm{rev})$ and Depth of Cut $(0.6 \mathrm{~mm}, 0.8 \mathrm{~mm}, 1.0 \mathrm{~mm})$. Here the cutting speed is predicted according to the spindle speed and workpiece dimension. Each test takes the surface roughness measurement by Mitutoyo conventional stylus probe, five measurements taken from each specimen, and the mean value used for the experimental reference in Table 3.

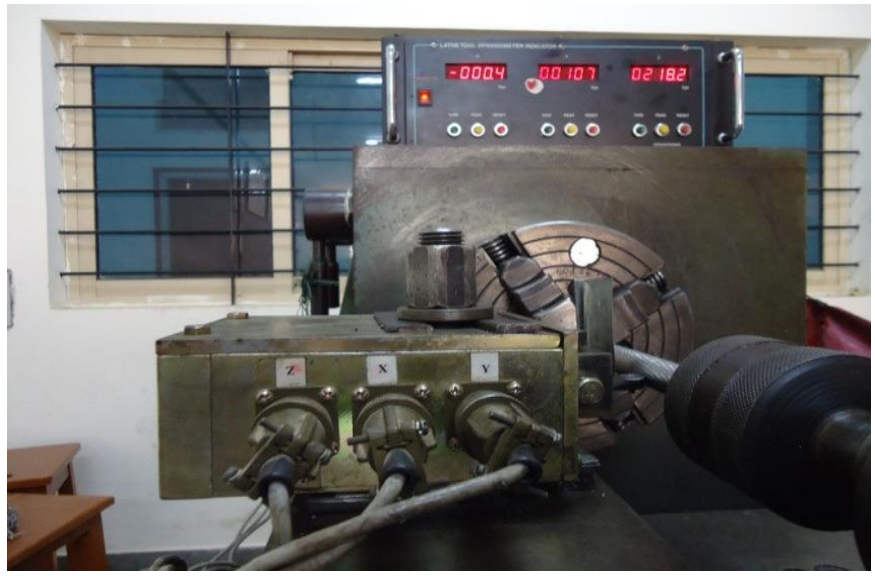

Figure 2. Experimental setup for measuring cutting force

\section{RESULT AND DISCUSSION}

\subsection{Mechanical characteristics}

A tensile testing machine did the tensile test for three different $\mathrm{Al}-5 \% \mathrm{Cu} / \mathrm{TiC} \mathrm{MMC}$. The prepared and testing samples are shown in Figure 3. Hardness test results for three different components of metal matrix composite showed in Table 2 by the in-situ method. The TiC has paly a vital role in increasing the hardness value of metal matrix composite. The specimen has contained $6 \% \mathrm{TiC}$, and its hardness value is 65.26. specimens 2 and 3, TiC percentage, increased while the hardness values also increased. Table 2 shows the mechanical properties of different metal matrix composite. During increases the TiC composite, which reduces the ductility of the metal matrix composite (3.12 to 1.54 ).

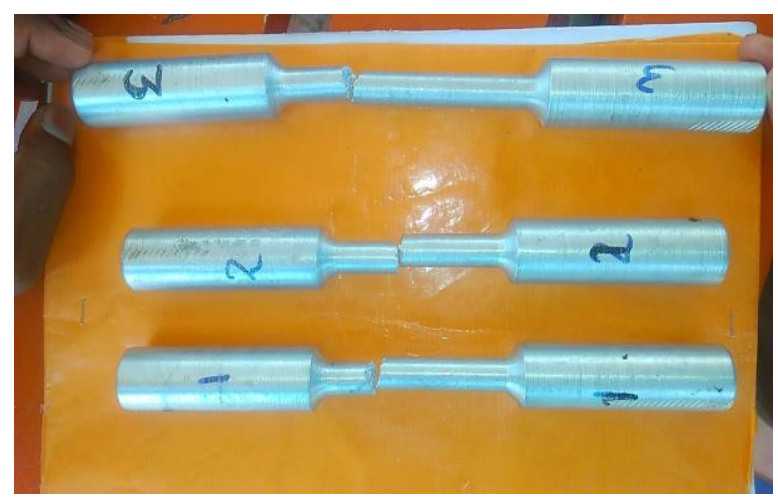

Figure 3. The specimen under the tensile test 


\subsection{Cutting force and surface quality}

The specimen is machined by the uncoated carbide cutting tool in CNC machining. The tool dynamometer is used to measure the cutting force induced by the cutting tool. From this experiment, we observed that the Depth of Cut decreased cutting speed was increased, and also the cutting force decreased. Figure 4 shows the cutting speed in the various metal matrix composite. In this experiment, the feed rate at a constant rate of $0.24 \mathrm{~mm} / \mathrm{rev}$. The cutting speed increased at the $50 \mathrm{~m} / \mathrm{min}, 90 \mathrm{~m} / \mathrm{min}$, and $130 \mathrm{~m} / \mathrm{min}$. The surface quality of the specimen was analyzed by SEM in Figure 5. Figure 5 shows the surface roughness value of $\mathrm{Al}-5 \% \mathrm{Cu} / \mathrm{TiC}$ composite. The results project the maximum cutting speed produced the good surface roughness.
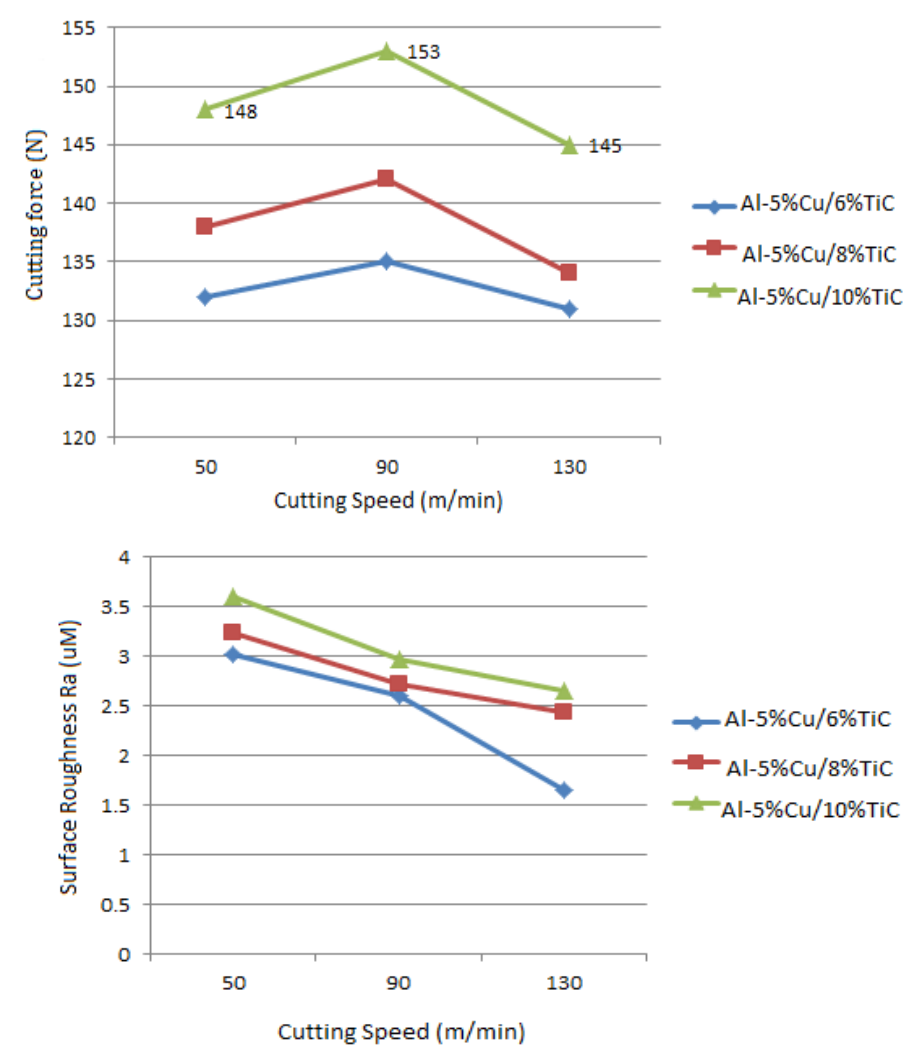

Figure 4. The Relation between cutting speed with Cutting force and surface roughness
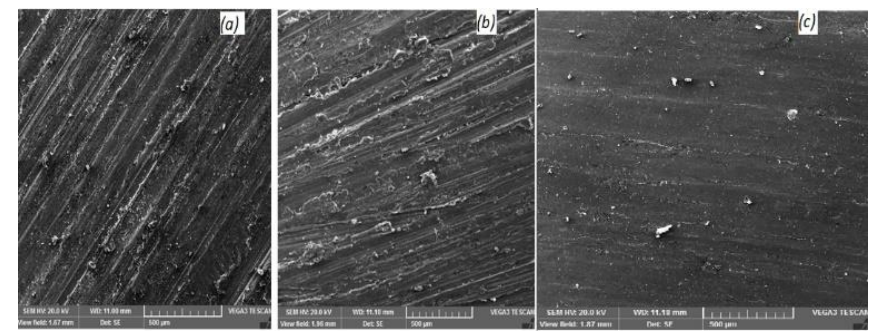

(a) $50 \mathrm{~m} / \mathrm{min}$; (b) $90 \mathrm{~m} / \mathrm{min}$; (c) $130 \mathrm{~m} / \mathrm{min}$

Figure 5. The SEM analysis of machined specimen surface at different cutting speed
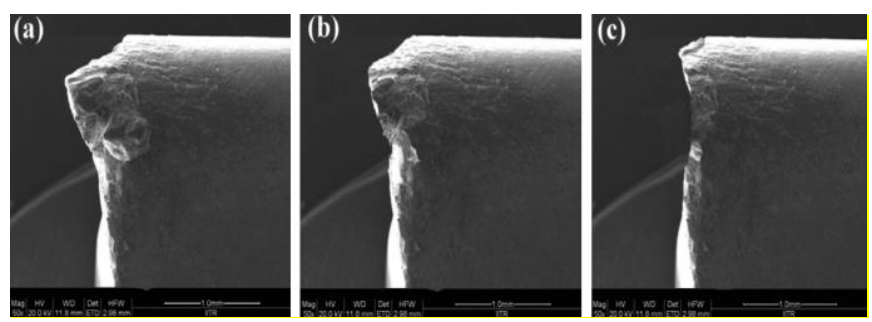

Figure 6. The SEM analysis of build-up edge in cutting tool

If the cutting force increased, the metal removal rate also increased; It raises the wear rate in the cutting tool. So the different cutting speeds carried out in metal matrix composite to predict the optimal solution for wear analysis. The cutting tool wear study investigated by SEM analysis in Figure 6.

\section{CONCLUSION}

Engine components need to resist high vibrational and temperature. In general, $\mathrm{Al}-\mathrm{Cu} / \mathrm{TiC}$ has excellent thermal characteristics [18]. This present study used to justify the excellent mechanical characteristics of MMC by the various testing method. $\mathrm{Al}-5 \% \mathrm{Cu}$ metal matrix mixed with various percentages of Titanium Carbide by the in-situ method for analyzing the strength of MMC. The study used to analyze the mechanical properties, machinability characteristics of metal matrix composite, and the cutting tool analysis by various techniques. The following points concluded from this work,

(1) Hardness and tensile strength directly proportional to the percentage of $\mathrm{TiC}$, while increasing the $\mathrm{TiC}$ range, the hardness and tensile also increased.

(2) The elongation range is indirectly proportional to the ductility of MMC. Table 2 results show the while increasing the TiC percentage, and it reduced the elasticity of the MMC.

(3) Based on the above investigation, the higher cutting speed induced the lower cutting force. So the good surface roughness value was achieved by higher cutting at $130 \mathrm{~m} / \mathrm{min}$.

(4) The cutting force increased while the wear occurs on the cutting tool is higher. So the Build-Up Edge formation was increased at the lower cutting speed.

\section{REFERENCES}

[1] Tjong, S.C., Ma, Z.Y. (2000). Microstructural and mechanical characteristics of in situ metal matrix composites. Materials Science and Engineering: R: Reports, 29(3-4): 49-113. https://doi.org/10.1016/S0927796X(00)00024-3

[2] Kennedy, A.R., Weston, D.P., Jones, M.I. (2001). Reaction in Al-TiC metal matrix composites. Materials Science and Engineering: A, 316(1-2): 32-38. https://doi.org/10.1016/S0921-5093(01)01228-X

[3] Bandyopadhyay, N.R., Ghosh, S., Basumallick, A. (2007). New generation metal matrix composites. Materials and Manufacturing Processes, 22(6): 679-682. https://doi.org/10.1080/10426910701384872

[4] Florea, R.M. (2017). Metal-Ceramic composites via "in situ" methods. In IOP Conference Series. Materials 
Science and $\quad$ Engineering, $227(1)$. https://doi.org/10.1088/1757-899X/227/1/012044

[5] Miracle, D.B. (2005). Metal matrix composites-from science to technological significance. Composites science and technology, 65(15-16): 2526-2540. https://doi.org/10.1016/j.compscitech.2005.05.027

[6] Lee, K.B., Sim, H.S., Kwon, H. (2005). Reaction products of $\mathrm{Al} / \mathrm{TiC}$ composites fabricated by the pressureless infiltration technique. Metallurgical and materials transactions A, 36(9): 2517-2527. http://dx.doi.org/10.1007/s11661-006-0052-8.

[7] Mukherjee, I., Ray, P.K. (2006). A review of optimization techniques in metal cutting processes. Computers \& Industrial Engineering, 50(1-2): 15-34. https://doi.org/10.1016/j.cie.2005.10.001

[8] Ozcatalbas, Y. (2003). Investigation of the machinability behaviour of Al4C3 reinforced Al-based composite produced by mechanical alloying technique. Composites Science and Technology, 63(1): 53-61. https://doi.org/10.1016/S0266-3538(02)00177-X

[9] Sahin, Y., Kok, M., Celik, H. (2002). Tool wear and surface roughness of $\mathrm{Al} 2 \mathrm{O} 3$ particle-reinforced aluminium alloy composites. Journal of Materials Processing Technology, 128(1-3): 280-291. https://doi.org/10.1016/S0924-0136(02)00467-3

[10] Manna, A., Bhattacharayya, B. (2005). Influence of machining parameters on the machinability of particulate reinforced $\mathrm{Al} / \mathrm{SiC}-\mathrm{MMC}$. The International Journal of Advanced Manufacturing Technology, 25(9-10): 850856. https://doi.org/10.1007/s00170-003-1917-2

[11] Ciftci, I., Turker, M., Seker, U. (2004). Evaluation of tool wear when machining SiCp-reinforced Al-2014 alloy matrix composites. Materials \& design, 25(3): 251-255. https://doi.org/10.1016/j.matdes.2003.09.019
[12] Chambers, A.R. (1996). The machinability of light alloy MMCs. Composites Part A: Applied Science and Manufacturing, 27(2): 143-147.

[13] Krishnan, B.R., Ramesh, M., (2019). Experimental evaluation of Al-Zn-A12O3 composite on piston analysis by CAE tools. Mechanics and Mechanical Engineering, 23(1): 212-217. https://doi.org/10.2478/mme-2019-0028

[14] Looney, L.A., Monaghan, J.M., O'Reilly, P. and Taplin, D.M.R., (1992). The turning of an Al/SiC metal-matrix composite. Journal of materials processing technology, 33(4): 453-468.

[15] Dinesh, S., Antony, A.G., Karuppusamy, S., Kumar, B.S., Vijayan, V. (2016). Experimental investigation and optimization of machining parameters in CNC turning operation of duplex stainless steel. Asian Journal of Research in Social Sciences and Humanities, 6(10): 179195. https://doi.org/10.5958/2249-7315.2016.01006.6

[16] Dinesh, S., Antony, A.G., Rajaguru, K., Vijayan, V. (2016). Investigation and prediction of material removal rate and surface roughness in CNC turning of EN24 alloy steel. Asian Journal of Research in Social Sciences and Humanities, 6(8): 849-863. https://doi.org/10.5958/2249-7315.2016.00654.7

[17] Tamizharasan, T., Senthilkumar, N., Selvakumar, V., Dinesh, S. (2019). Taguchi's methodology of optimizing turning parameters over chip thickness ratio in machining P/M AMMC. SN Applied Sciences, 1(2): 160. https://doi.org/10.1007/s42452-019-0170-8

[18] Bassani, P., Gariboldi, E., Ripamonti, D. (2008). Thermal analysis of $\mathrm{Al}-\mathrm{Cu}-\mathrm{Mg}-\mathrm{Si}$ alloy with $\mathrm{Ag} / \mathrm{Zr}$ additions. Journal of thermal analysis and calorimetry, 91(1): 29-35. https://doi.org/10.1007/s10973-007-83761 